16. Kitay DZ, Harbort RA 1975 Iron and folic acid deficiency in pregnancy. Clin Perinatol 2:255

17. Kochanowski BA, Sherman AR 1982 Cellular growth in iron-deficient rat pups. Growth 46:126

18. Lee YH, Layman DK, Bell RA 1981 Glutathione peroxidase activity in irondeficient rats. J Nutr 1 1 1:194

19. Lowry OH, Rosebrough NJ, Farr AL, Randall RJ 1951 Protein measurement with the Folin phenol reagent. J Biol Chem 193:265

20. Macdougall LG 1972 Red cell metabolism in iron deficiency anemia. III. The relationship between glutathione peroxidase, catalase, serum vitamin $\mathrm{E}$, and susceptibility of iron-deficient red cells to oxidative hemolysis. J Pediatr 80:775

21. Rudolph AM, Heymann MA 1974 Fetal and neonatal circulation and respiration. Annu Rev Physiol 36:187

22. Shepard TH, Mackler B, Finch CA 1980 Reproductive studies in the iron- deficient rat. Teratology 22:329

23. Siimes MA, Refino C, Dallman PR 1980 Manifestations of iron deficiency at various levels of dietary iron intake. Am J Clin Nutr 33:570

24. Tanswell AK, Freeman BA 1984 Pulmonary antioxidant enzyme maturation in the fetal and neonatal rat. I. Developmental profiles. Pediatr Res 18:584

25. Tanswell AK, Freeman BA 1984 Differentiation-arrested rat fetal lung in primary monolayer cell culture. III. Antioxidant enzyme activity. Exp Lung Res, in press

26. Turrens JF, Freeman BA, Crapo JD 1982 Hyperoxia increases $\mathrm{H}_{2} \mathrm{O}_{2}$ release by lung mitochondria and microsomes. Arch Biochem Biophys 217:411

27. Widdowson EM 1974 Nutrition. In: Davis JA, Dobbing J (eds) Scientific Foundations of Paediatrics. Heinemann, London, pp 44-55

28. Yam J, Frank L, Roberts RJ 1978 Oxygen toxicity: comparison of lung biochemical responses in neonatal and adult rats. Pediatr Res 12:115

\title{
Cardiovascular Changes in Group B Streptococcal Sepsis in the Piglet: Response to Indomethacin and Relationship to Prostacyclin and Thromboxane $\mathbf{A}_{2}$
}

\author{
BEATRIZ RUNKLE, RONALD N. GOLDBERG, MURRAY M. STREITFELD, MARTIN R. CLARK, \\ ELENA BURON, EMMALEE S. SETZER, AND EDUARDO BANCALARI
}

Department of Pediatrics (Division of Neonatology) [B.R., R.N.G., El.B., E.S.S., E.B.] and Departments of Microbiology [M.M.S.] and Obstetrics and Gynecology [M.R.C.], University of Miami School of Medicine, Miami, Florida 33101

\section{Summary}

Seventeen piglets were infected with a continuous intravenous infusion of live group B $\beta$-hemolytic streptococci (GBS). Hemodynamic changes were recorded, and blood samples were drawn for measurement of thromboxane $B_{2}\left(T_{x B}\right)$ (stable metabolite of thromboxane $A_{2}$ ) and 6-keto-PGF $1 \alpha$ (stable metabolite of prostacyclin). Control animals $(n=9)$ received only bacteria, while treatment animals $(n=8)$ received indomethacin, $3 \mathrm{mg} / \mathrm{kg} \mathrm{IV}$, $15 \mathrm{~min}$ after the start of the bacterial infusion. Control animals responded to the bacteria within $15 \mathrm{~min}$ with marked elevation in mean pulmonary artery pressure ( $(\overline{\mathrm{Ppa}})$ from $15 \pm 8$ to $39 \pm 6$ $\mathrm{mm} \mathrm{Hg}$ and decline in $\mathrm{PaO}_{2}$ from $80 \pm 11$ to $51 \pm 6 \mathrm{~mm} \mathrm{Hg}$ and cardiac output $(\mathrm{CO})$ from $0.24 \pm 0.07$ to $0.13 \pm 0.07$ liters $/ \mathrm{min} /$ kg. Mean arterial blood pressure $(\overline{A o P})$ significantly decreased from baseline value of $95 \pm 13$ to $51 \pm 32 \mathrm{~mm} \mathrm{Hg}$ by $180 \mathrm{~min}$. In animals treated with indomethacin, these changes were reversed or significantly attenuated. The hemodynamic changes were associated temporally with elevations in plasma concentrations of $\mathrm{TxB}_{2}$ or 6-keto- $\mathrm{PGF}_{1 \alpha}$. In the first $60 \mathrm{~min}$, $\mathrm{TxB}_{2}$ levels in both groups correlated with $\overline{\mathrm{Ppa}}(r=0.72, p<0.001)$ and

Received August 4, 1983; accepted February 7, 1984

Address correspondence to Ronald N. Goldberg, M.D., Department of Pediatrics (R-131), University of Miami School of Medicine, P.O. Box 016960, Miami, FL 33101 .

This work was supported in part by National Institute of Child Health and Human Development Grants I ROI HD14940-03 and 5 RO1 HL25023-03, March of Dimes Grant 6-303, United Cerebral Palsy Research and Educational Foundation Sydney Farber Memorial Research Award R-310-80, and Project: New Born. Presented in part to the Society for Pediatric Research, Washington, D. C., May 5, 1983.
$\mathrm{PaO}_{2}(r=-0.60, p<0.001)$. A strong negative correlation between $\mathrm{TxB}_{2}$ and $\mathrm{CO}$ was observed over the first $180 \mathrm{~min}(r=$ $-0.73, p \leq 0.001$ ). There was a statistically significant correlation between $\overline{\mathrm{AoP}}$ and 6-keto-PGF ${ }_{1 \alpha}$ concentration between 60 and $180 \min (r=-0.54, p<0.002)$. Indomethacin improved the hemodynamic function in this model of GBS sepsis. This improvement was related in part to inhibition of synthesis of thromboxane $A_{2}$ and prostacyclin.

\section{Abbreviations}

GBS, group B streptococci

AoP, aortic blood pressure

$\mathrm{CO}$, cardiac output

Ppa, pulmonary artery pressure

Ppaw, pulmonary wedge pressure

Pra, right atrial pressure

$\mathbf{T x B}_{2}$, thromboxane $\mathrm{B}_{2}$

Since 1962 when Northover and Sabramanian (18) first used sodium salicylate to treat endotoxin shock in dogs, numerous investigators have documented the beneficial effects of nonsteroidal anti-inflammatory agents on hemodynamics and survival in experimental endotoxin shock $(6-9,14,15,20-22,32)$. These studies have led to further work implicating prostaglandins and thromboxanes in the pathophysiology of endotoxin shock (1-3, 10-12). Particular attention has focused on the roles of thromboxane $\mathrm{A}_{2}$, a vasoconstrictor and platelet-aggregating agent, and prostacyclin, a vasodilator and anti-aggregating agent. 
The hemodynamic consequences of experimental $\beta$-hemolytic GBS disease strongly resemble those of endotoxin-induced illness $(16,23)$. However, in contrast to the extensive work done in endotoxin models, the effects of cyclooxygenase inhibitors in GBS sepsis models have only recently begun to be studied (24, 26).

The present study was undertaken to assess the effects of treatment with indomethacin on hemodynamics and survival in a highly lethal model of GBS sepsis. The associations between plasma levels of the stable metabolites of thromboxane $A_{2}$ and prostacyclin and the observed cardiovascular events were also explored.

\section{MATERIALS AND METHODS}

Bacterial preparation. Group B $\beta$-hemolytic streptococci (type Ic) were isolated from the blood of an infant who developed early onset disease and died at the University of Miami/Jackson Memorial Hospital Neonatal Intensive Care Unit. Bacteria for each animal experiment were incubated $18 \mathrm{~h}(16,23)$ in ToddHewitt broth at $37^{\circ} \mathrm{C}$. The broth culture was centrifuged at 1700 $\mathrm{rpm}$ for $30 \mathrm{~min}$ and the bacterial pellet was resuspended in sterile Ringer's lactate solution with $5 \%$ dextrose to an approximate concentration of $10^{9}-10^{10}$ organisms $/ \mathrm{cc}$.

Animal model. Piglets, ages 2 to 4 weeks, were anesthetized with pentobarbital $(30 \mathrm{mg} / \mathrm{kg})$ intraperitoneally and allowed to breathe spontaneously. The femoral arteries and veins were cannulated bilaterally for blood pressure measurement, blood sampling, and fluid infusions. The left external jugular vein was cannulated and the catheter was advanced into the right atrium for measurement of pressure and injection of thermal indicator for cardiac output measurement. A 5 F Swan-Ganz flow-directed thermodilution catheter was introduced into the right external jugular vein and advanced under fluoroscopy into the left pulmonary artery. This catheter was used for measurement of Ppa, Ppaw, and CO (1950-American Edwards Laboratories, Santa Ana, CA). A second thermodilution catheter (4F, American Edwards Laboratories) was advanced from the femoral artery into the high descending aorta. Simultaneous tracings of the thermodilution curves of each catheter were made with a twochannel recorder (Model 15-6327-57, Gould, Inc., Cleveland, $\mathrm{OH}$ ) in seven animals.

Vascular pressures were measured with pressure transducers (Model P23; Gould-Statham Instruments, Hato Rey, PR) and recorded on a multichannel recorder (Model 5 polygraph, S2925T25, Grass Instruments, Quincy, MA).

Arterial blood gases were measured at preset intervals $(\mathrm{pH} /$ Blood Gas Analyzer 113, Instrumentation Laboratory, Inc., Lexington, MA) and rectal temperature was measured continuously. Skin temperature was maintained constant at $38.0^{\circ} \mathrm{C}$ by means of a servo-controlled radiant warmer. Two animals had continuous measurements of $\mathrm{PaO}_{2}$ via an indwelling arterial catheter (Searle Neonatal Oxygen Probe, 4 Fr., Searle Medical Products, Dallas, TX).

Following the cannulations, a stabilization period of $1 \mathrm{~h}$ was observed prior to obtaining baseline measurements. Three baseline measurements of vital signs, cardiac output, arterial blood gases, hematocrit, Ppa, Ppaw, Pra, and AoP were obtained at 20min intervals in the hour preceding the bacterial infusion and averaged. Cardiac output was measured in duplicate, averaged, and corrected for weight. Following the start of the bacterial infusion, these parameters were recorded at 15 and $30 \mathrm{~min}$, and then every 30 min until the animal expired or $6 \mathrm{~h}$ had elapsed. Results are displayed graphically for the first $4 \mathrm{~h}$ because of the high mortality in the study groups after that time.

Induction of sepsis. Bacterial infusion was begun immediately after baseline values were obtained. Bacteria were infused through a femoral vein at a rate calculated to deliver approximately $1.2 \times 10^{8}$ organisms $/ \mathrm{kg} / \mathrm{min}$. This infusion was continued until the animal died or $6 \mathrm{~h}$ had elapsed. Blood cultures were obtained before, midway through, and at the end of the bacterial infusion in 10 animals.

Animals were randomly assigned to two groups. The control group $(n=9)(\bar{x} \pm \mathrm{SD}$; weight, $3353 \pm 1358 \mathrm{~g}$; age, $21 \pm 4$ days $)$ received only bacteria. The treatment group $(n=8)$ (weight, $3385 \pm 1322 \mathrm{~g}$; age, $19.5 \pm 4$ days) received indomethacin (3 $\mathrm{mg} / \mathrm{kg}$, Merck Sharp and Dohme Research Laboratories, West Point, PN) 15 min after the start of the bacterial infusion. Indomethacin was infused through the contralateral femoral vein.

Assay for thromboxane $B_{2}$ and 6-Keto-PGF $F_{1 \alpha}$. Blood samples $(1 \mathrm{ml})$ for radioimmunoassay for $\mathrm{TxB}_{2}$, the stable metabolite of thromboxane $\mathrm{A}_{2}$, and 6-keto-PGF ${ }_{1 \alpha}$, the stable metabolite of prostacyclin, were collected in tubes containing aspirin and EDTA $(0.41$ and $1.95 \mathrm{mg} / \mathrm{ml}$ for $1 \mathrm{ml}$ blood, respectively) from seven control and eight treatment animals. The assay was not available when the first two experiments were performed. Plasma from these samples was extracted with ethanol, centrifuged, and dried under liquid nitrogen before being reconstituted in 0.5-1.0 $\mathrm{ml}$ of phosphate-buffered saline containing gelatin. Antisera for the $\mathrm{TxB}_{2}$ and 6-keto-PGF $\mathrm{F}_{1 \alpha}$ assay were obtained from Dr. F. Fitzpatrick (5) and Dr. J. Salmon (25), respectively, and the radioimmunoassay was performed as described. Tritiated ligand for each assay was purchased from New England Nuclear Corporation (Boston, MA). After commencement of the bacterial infusion, arterial samples for 6-keto-PGF ${ }_{1 \alpha}$ and $\mathrm{TxB}_{2}$ were drawn at 15,30 , and $60 \mathrm{~min}$, and then hourly.

Statistics. Statistical analysis was performed using the paired $t$ test, two-sample rank test, and repeated measures analysis of variance.

\section{RESULTS}

Hemodynamic measurements at baseline and $15 \mathrm{~min}$ after the onset of GBS infusion were comparable in control and indomethacin-treated animals. Pulmonary artery pressure increased early in both groups (Fig. 1) and was markedly elevated compared to baseline at $15 \mathrm{~min}(p<0.001)$. Arterial oxygen tension (Fig. 1) was significantly lower than baseline at $15 \mathrm{~min}(p<0.002)$. In the two animals with indwelling arterial $\mathrm{PO}_{2}$ catheters, the decline in $\mathrm{PaO}_{2}$ was noted to occur after the rise in $\overline{\mathrm{Ppa}}$.

After $15 \mathrm{~min}, \overline{\mathrm{Ppa}}$ in control animals declined slowly and by $120 \mathrm{~min}$ had reached a plateau still significantly higher than baseline $(p<0.002)$ (Fig. 1). Animals treated with indomethacin at $15 \mathrm{~min}$ after the start of the bacterial infusion displayed an immediate reduction in Ppa to baseline values, followed by a gradual increase after $60 \mathrm{~min}$. The pattern of $\overline{\mathrm{Ppa}}$ in the two groups was significantly different between 30 and 120 min $(p<$ 0.001 ). After $120 \mathrm{~min}$, however, the pattern of $\overline{\mathrm{Ppa}}$ in the treatment animals was comparable to that of the controls.

Arterial oxygen tension in control animals remained low throughout much of the study, then increased gradually after 120 min. In contrast, $\mathrm{PaO}_{2}$ increased to baseline values immediately following the administration of indomethacin and was significantly different in the two groups until $120 \mathrm{~min}(p<0.05)$.

After the initial marked reduction at $15 \mathrm{~min}(p<0.001)$, cardiac output remained stable in control animals throughout the experiment (Fig. 2). By $60 \mathrm{~min}$ after the onset of the bacterial infusion, cardiac output in the treatment group had risen to values similar to baseline. Cardiac output remained stable until approximately $240 \mathrm{~min}$ and declined thereafter. A significant difference in cardiac output $(p<0.05)$ between controls and treatment animals was observed during the period from 30 to $120 \mathrm{~min}$ following the onset of bacterial infusion.

Aortic blood pressure in the control group was maintained at baseline levels until $60 \mathrm{~min}$, after which a steady deterioration was observed (Fig. 2). Indomethacin-treated animals, on the other hand, maintained a normal blood pressure for at least $4 \mathrm{~h}$. The pattern of blood pressure in the two groups was significantly different between 30 and $180 \mathrm{~min}(p<0.05)$. 

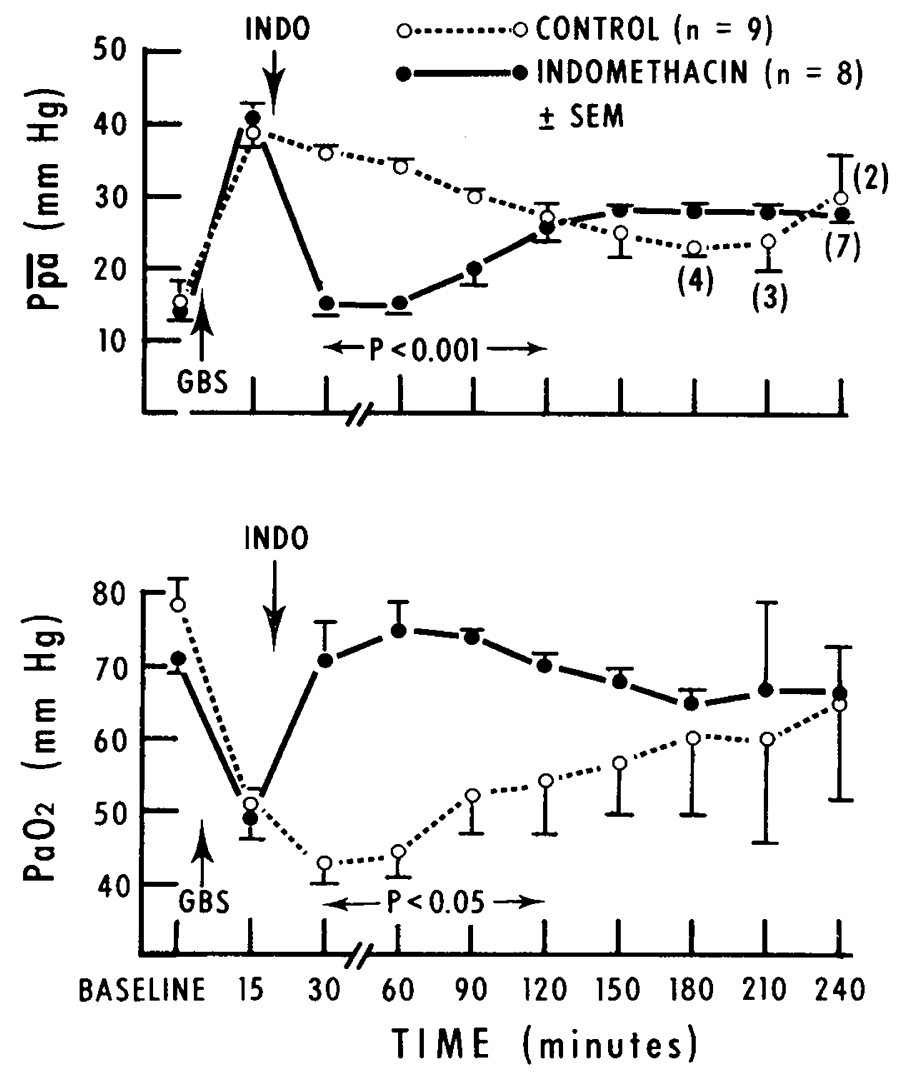

Fig. 1. Responses of mean pulmonary artery pressure and $\mathrm{PaO}_{2}$ to infusion of GBS. Effect of indomethacin (INDO) on these measurements in the treatment group compared to the control group are shown. Numbers represent animals surviving during that time period. Significant differences between groups are indicated.

Mean $\mathrm{TxB}_{2}$ levels (Fig. 3) were significantly increased $(p<$ 0.01 ) compared to baseline values at $15 \mathrm{~min}$ in both groups, and remained high in the control animals. Values of $\mathrm{TxB}_{2}$ in treatment animals returned to baseline after indomethacin administration and remained at that level throughout the remainder of the experiment. Treatment animals had significantly lower $\mathrm{TxB}_{2}$ levels than control animals from 30 to $180 \mathrm{~min}(p<0.01)$.

In the first $60 \mathrm{~min}, \mathrm{TxB}_{2}$ levels in both groups correlated with $\overline{\mathrm{Ppa}}(r=0.72, p<0.001)$ and $\mathrm{PaO}_{2}(r=-0.60, p<0.001)$. A strong negative correlation between $\mathrm{TxB}_{2}$ and $\mathrm{CO}$ was observed over the first $180 \mathrm{~min}(r=-0.73, p<0.001)$ (Fig. 4).

Plasma concentrations of 6-keto-PGF ${ }_{1 \alpha}$ (Fig. 3) were low at first in both groups and remained low in control animals until $120 \mathrm{~min}$, at which time levels tended to increase $(p<0.08)$ compared to baseline. This trend became significant $(p<0.05)$ by $180 \mathrm{~min}$. In treatment animals, 6-keto-PGF ${ }_{1 \alpha}$ remained at low levels throughout the experiment. The pattern of 6-keto$\mathrm{PGF}_{1 \alpha}$ concentrations differed significantly between the two groups from 30 to $180 \mathrm{~min}(p<0.05)$. There was a statistically significant correlation between $\overline{\mathrm{AoP}}$ and 6-keto- $\mathrm{PGF}_{1 \alpha}$ concentration between 60 and $180 \mathrm{~min}(r=-0.54, p<0.002)$.

Blood cultures obtained before the start of the bacterial infusion were sterile, while all the cultures obtained during and at the end of the infusions grew group B streptococci.

Animals alive after $6 \mathrm{~h}$ of bacterial infusion were considered survivors. All of the control animals died, while three of eight indomethacin-treated animals survived. Mean survival time in the treatment group was $311 \pm 49 \mathrm{~min}$, as compared to $202 \pm$ $62 \mathrm{~min}$ in controls $(p<0.01)$.

\section{DISCUSSION}

The effects of cyclooxygenase inhibitors in experimental models of GBS sepsis have recently been examined. Rojas and colleagues $(23,24)$ described the pulmonary vascular effects of infusion of GBS and its extracellular toxin in yearling sheep. The effects observed (i.e., an initial period of marked pulmonary hypertension followed by evidence of increased pulmonary vascular permeability) were similar to those described by Ogletree et al. in an endotoxin model (19). In both studies, the initial phase of pulmonary hypertension was prevented by indomethacin pretreatment and subsequent continuous infusion; however, the second phase of increased pulmonary vascular permeability was not affected. Both $\mathrm{TxB}_{2}$ and 6-keto-PGF ${ }_{1 \alpha}$ measured in lung lymph in Rojas' study increased during the initial phase of pulmonary hypertension and decreased, although not to baseline levels, in the second phase (24). When indomethacin was given prior to administration of GBS toxin, no increase in these substances was found. It should be noted that the dose of GBS exotoxin used resulted in pulmonary vascular changes without any reduction of cardiac output or systemic blood pressure. Thus, the possible effect of indomethacin on either shock or survival could not be evaluated. Using a different model, Short et al. (26) were able to demonstrate a significant increase in survival in suckling rats when indomethacin was administered either concomitantly with or $4 \mathrm{~h}$ after injection of GBS.

The present study supports and extends the previously cited works by evaluating the hemodynamic correlates of GBS sepsis and their relationship to $\mathrm{TxB}_{2}$ and 6-keto- $\mathrm{PGF}_{1 \alpha}$ over a prolonged

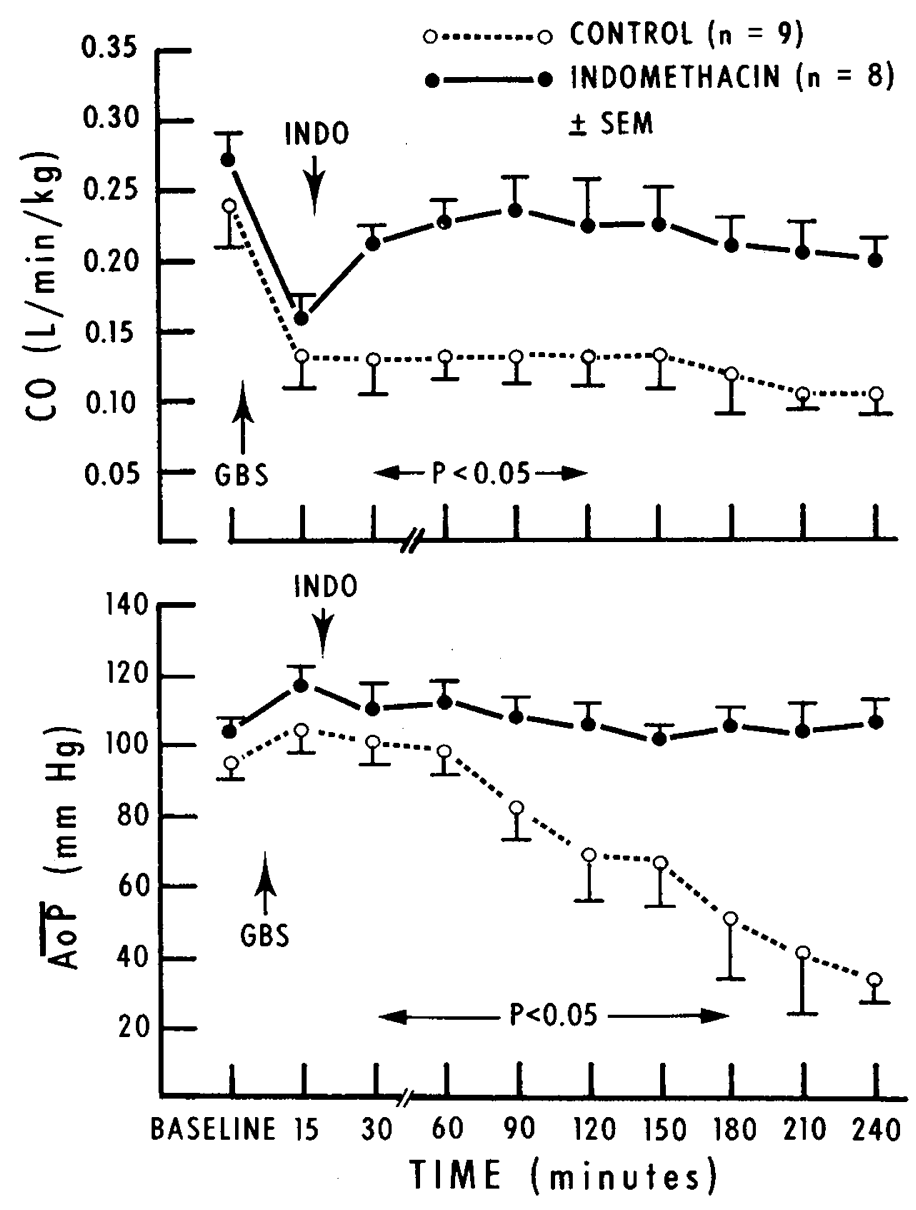

Fig. 2. Responses of cardiac output and mean systemic arterial pressure to infusion of GBS. Effect of indomethacin $(I N D O)$ on these measurements in the treatment and control group is shown. Significant differences between groups are indicated. 
period of time. Our model differs from the above GBS models and from endotoxin models in that it employs a continuous infusion of organisms rather than a bolus of either toxin or bacteria and, in fact, this may result in an infusion of both toxin and live bacteria. In addition, indomethacin is given $15 \mathrm{~min}$ after
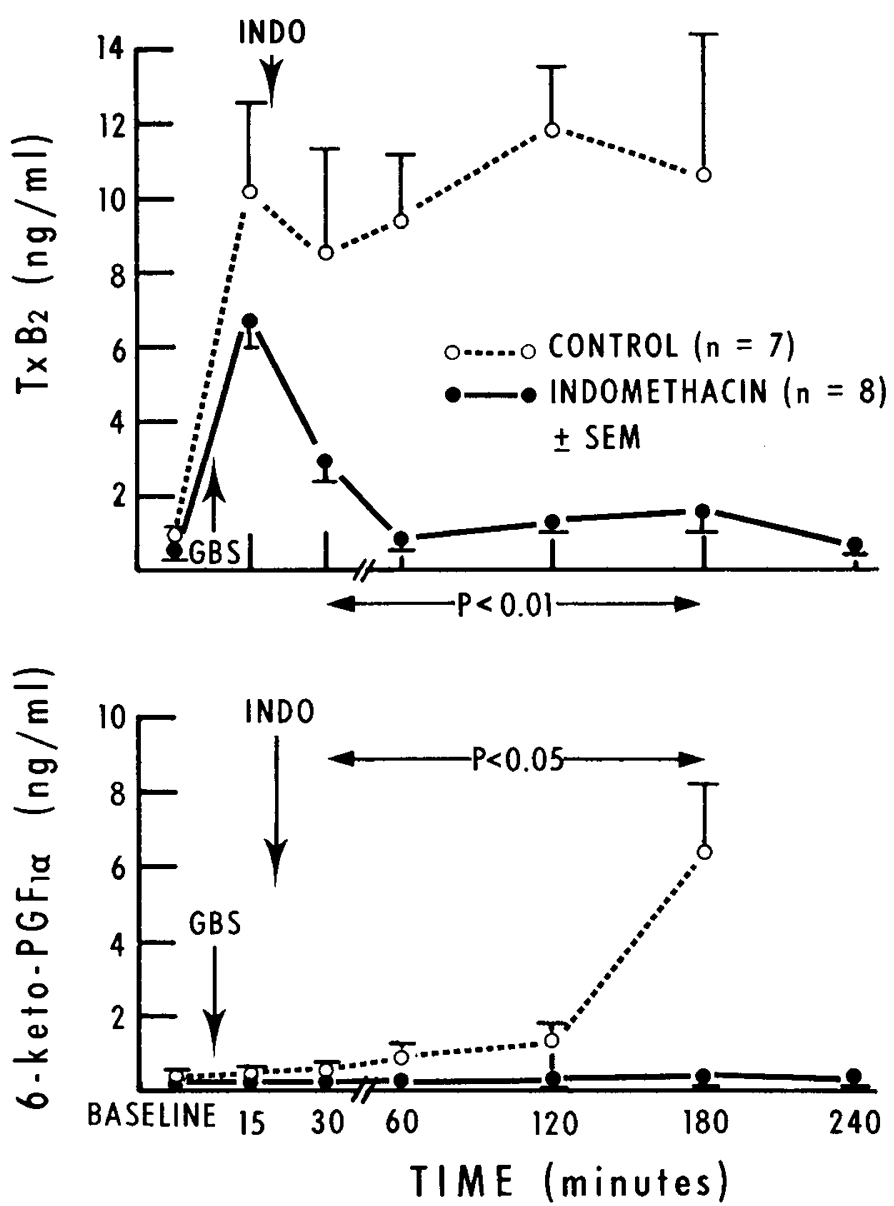

Fig. 3. Levels of $\mathrm{TxB}_{2}$ and 6-keto-PGF $\mathrm{P}_{1 \alpha}$ in treatment and control groups are shown. Significant differences between groups are indicated. INDO, indomethacin.
GBS sepsis is induced. The presence of an ongoing bacterial stimulus may account for the persistent elevation in plasma $\mathrm{TxB}_{2}$ concentrations seen in control animals, in contrast to the peak and later decline in concentrations of $\mathrm{TxB}_{2}$ reported in other models $(10,12)$.

The temporal association of early pulmonary hypertension with an elevation in $\mathrm{TxB}_{2}$ concentrations has been previously observed in Rojas' model, as well as in various endotoxin models $(10,12,24)$. Thromboxane $A_{2}$, a potent vasoconstrictor, appears to mediate the early increase in pulmonary artery pressure. Interestingly, pulmonary artery pressure in control animals in the present study begins to decline slowly and levels off at approximately $120 \mathrm{~min}$, despite persistently high $\mathrm{TxB}_{2}$ concentrations. This pattern of Ppa has been observed by Ogletree and colleagues in their endotoxin model (19). Furthermore, in the indomethacin-treated animals in the current study, Ppa increases in the face of persistently low $T \times B_{2}$ concentration. This suggests that the late, less pronounced, pulmonary hypertension is not related to a cyclooxygenase metabolite.

The etiology of the decline in $\mathrm{CO}$ in this and other septic shock models is not clear. Right heart failure secondary to severe pulmonary hypertension has been postulated (13), but Ogletree et al. (19) have produced marked increases in $\overline{\mathrm{Ppa}}$ in sheep, by administering endotoxin in a dose too low to cause any systemic changes. Rojas et al. (23) have elicited the same response with group B streptococcal exotoxin. If pulmonary vasoconstriction alone were responsible for the reduction in $\mathrm{CO}$, then an immediate return of $\mathrm{CO}$ to baseline levels would be expected as soon as Ppa returns to normal. In fact, although Ppa is normal by 10 15 min after indomethacin administration, $\mathrm{CO}$ does not return to baseline values until $30 \mathrm{~min}$ after indomethacin, suggesting the involvement of another mechanism. A humoral myocardial depressant has been postulated to occur with high levels of positive end expiratory pressure (4) and with experimental pulmonary embolism (30). Depression of myocardial function in these studies has been prevented by pretreatment with either indomethacin or a selective inhibitor of thromboxane $A_{2}$ synthesis $(4,30)$. The possibility that thromboxane $A_{2}$ itself, or a related substance, has direct effects on cardiac function is suggested in the present study by the inverse correlation between plasma $\mathrm{TxB}_{2}$ and $\mathrm{CO}$.

The role of prostacyclin in the endotoxin model is also unclear.

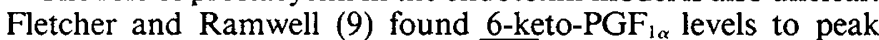
simultaneously with a decline in $\overline{\mathrm{AOP}}$ in a baboon endotoxin

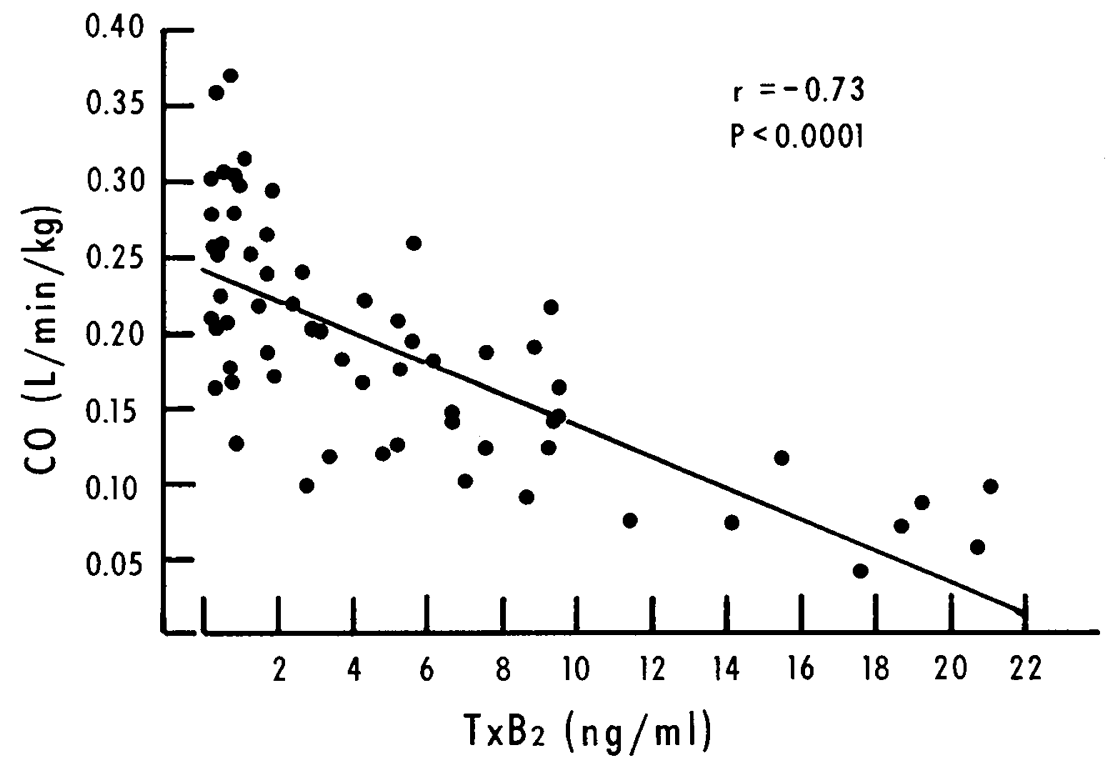

Fig. 4. Relationship between $T \times B_{2}$ and cardiac output over the first $180 \mathrm{~min}$ of the experiment. 
model. This was not confirmed by Webb et al. (31), who found no detectable levels of 6 -keto-PGF $F_{1 \alpha}$ in pigs given a bolus of endotoxin. In the latter study, prostacyclin infusion actually prevented the late drop in $\overline{\mathrm{AoP}}$. The fact that the latter authors sampled blood from the inferior vena cava may have had some bearing on the low concentration of 6-keto-PGF $F_{1 \alpha}$, as this substance is thought to be inactivated in peripheral tissues (17). Our findings suggest a temporal relationship between increasing levels of 6-keto-PGF ${ }_{1 \alpha}$ and the late decline in $\overline{\mathrm{AOP}}$ in control animals.

The hypoxemia noted in our model closely follows the onset of pulmonary hypertension. Early hypoxemia has been observed in endotoxin models $(19,27)$ and is thought to result from perfusion of areas of lung poorly ventilated as a result of bronchoconstriction. Snapper (27) has measured increases in airway resistance accompanying infusion of endotoxin and has shown that these changes were ameliorated by a cyclooxygenase inhibitor. Thromboxane $A_{2}$ has been implicated in the etiology of these abnormalities (29). However, Spannhake et al. (28) have questioned the relative contribution of thromboxane $A_{2}$ in the bronchoconstrictive response to endotoxin by demonstrating no difference in bronchoconstriction between control and endotoxin-treated animals when a thromboxane $\mathrm{A}_{2}$ synthetase inhibitor was used. They suggest a role for lipoxygenase products or a decrease in the autoinactivation of cyclooxygenase in the etiology of pulmonary function abnormalities in endotoxin-treated animals.

The theoretical possibility of right-to-left shunting across a probe-patent foramen ovale as a cause of hypoxemia related to pulmonary hypertension is of some concern. However, simultaneous thermodilution curves obtained from thermistors in both the pulmonary artery and high descending aorta did not give evidence of a right-to-left shunt in our animals, even when probe patency of the foramen ovale was found. Ductal patency was not observed.

Caution must be exercised in attempting to extrapolate the results of this experiment to the clinical setting. The model used is rapidly lethal unlike most cases of neonatal GBS disease. In addition, the dose of indomethacin is much higher than the dosage clinically employed for patent ductus arteriosus in the neonate. The absence of extrapulmonary right-to-left shunting also distinguishes this animal model from the human neonate.

In conclusion, the findings of the present study suggest that 1) indomethacin significantly improves hemodynamics and survival in a highly lethal model of group $\mathrm{B} \beta$-hemolytic streptococcal sepsis, 2) the hemodynamic alterations observed in controls coincide temporally with significant elevations in plasma concentrations of $\mathrm{TxB}_{2}$ and 6-keto-PGF $\mathrm{PG}_{1 \alpha}$, and 3) the hemodynamic improvements observed following indomethacin administration are in part related to either reduction in circulating thromboxane $\mathrm{A}_{2}$ or prevention of an increase in prostacyclin.

Acknowledgments. We thank Mr. Ralph N. Cicalese for his technical assistance throughout this project, Patricia Ayon de Lujan for preparing this manuscript, Janet Cassady for her assistance with the statistical analyses, and Dr. Mary Jane Jesse for her critical review of this manuscript. Bacterial typing was kindly performed by Dr. Carol J. Baker's Laboratory, Baylor College of Medicine, Houston, TX. Indomethacin was supplied by Merck Sharp and Dohme Research Laboratories.

\section{REFERENCES}

1. Bottoms GD, Templeton CB, Fessler JE, Johnson MA, Roesel OF, Ewert KM, Adams SB 1982 Thromboxane, prostaglandin $I_{2}$ (epoprostenol), and the hemodynamic changes in equine endotoxin shock. Am J Vet Res 43:999

2. Bult H, Beetens J, Vercruysse P, Herman AG 1980 Endotoxin-induced hypotension and blood levels of 6-keto-PGF $1-\alpha$. Adv Prostaglandin Thromboxane Res 7:839

3. Cook JA, Wise WC, Halushka PU 1980 Elevated thromboxane levels in the rat during endotoxic shock. J Clin Invest 65:277

4. Dunham BM, Grindlinger GA, Utsunomiya T, Krausz MM, Hechtman HB, Shepro D 1981 Role of prostaglandins in positive end-expiratory pressureinduced negative inotropism. Am J Physiol 241:H783

5. Fitzpatrick FA, Gorman RR, McGuire JC, Kelly RC, Wynalda MA, Sun FF 1977 A radioimmunoassay for thromboxane $B_{2}$. Anal Biochem 82:1

6. Fletcher JR 1982 The role of prostaglandins in sepsis. Scand J Infect Dis Suppl $31: 55$

7. Fletcher JR, Ramwell PW 1980 Indomethacin treatment following baboon endotoxin shock improves survival. In Schumer W, Spitzer J, Marshall B (eds) Advances in Shock Research. Alan R. Liss, Inc, New York, p 103

8. Fletcher JR, Ramwell PW 1977 Modification, by aspirin and indomethacin, of the hemodynamic and prostaglandin releasing effects of $E$. coli endotoxin in the dog. Br J Pharmacol 61:175

9. Fletcher JR, Ramwell PW 1978 Lidocaine or indomethacin improves survival in baboon endotoxin shock. J Surg Res 24:154

10. Fletcher JR, Ramwell PW, Harris RH 1981 Thromboxane, prostacyclin, and hemodynamic events in primate endotoxin shock. Adv Shock Res 5:143

11. Fletcher JR, Ramwell PW, Herman CM 1976 Prostaglandins and the hemodynamic course of endotoxin shock. J Surg Res 20:589

12. Frölich JC, Ogletree ML, Peskar BA, Brigham KL 1980 Pulmonary hypertension correlated to pulmonary thromboxane synthesis. Adv Prostaglandin Thromboxane Res 7:745

13. Halmagyi DFJ, Starzecki B, Horner GJ 1963 Mechanism and pharmacology of endotoxin shock in sheep. J Appl Physiol 18:544

14. Halushka PU, Wise WC, Cook JA 1981 Protective effects of aspirin in endotoxin shock. J Pharmacol Exp Ther 218:464

15. Hinshaw LB, Solomon LA, Erdos EG, Reins DA, Gunter BJ 1967 Effects of acetylsalicylic acid on the canine response to endotoxin. J Pharmacol Exp Ther 157:665

16. Meadow W, Meus P 1981 An animal model of neonatal sepsis: early and late hemodynamic and metabolic sequelae of Group B Beta strep sepsis in the piglet. Pediatr Res 15:672A

17. Moncada S, Vane JR 1980 Prostacyclin in the cardiovascular system. Adv Prostaglandin Thromboxane Res 6:48

18. Northover BJ, Subramanian G 1962 Analgesic antipyretic drugs as antagonists of endotoxin shock in dogs. J Pathol Bacteriol 83:463

19. Ogletree ML, Brigham KL 1982 Effects of cyclo-oxygenase inhibitors on pulmonary vascular responses to endotoxin in unanesthetized sheep. Prostaglandins Leukotrienes Med 8:489

20. Parratt JR, Sturgess RM $1975 E$. coli endotoxin shock in the cat: treatment with indomethacin. Br J Pharmacol 53:485

21. Parratt JR, Sturgess RM 1975 The effects of the repeated administration of sodium meclofenamate, and inhibitor of prostaglandin synthetase, in feline endotoxin shock. Circ Shock 2:301

22. Parratt JR, Sturgess RM 1974 The effect of indomethacin on the cardiovascular and metabolic responses to $E$. coli endotoxin in the cat. $\mathrm{Br} \mathrm{J}$ Pharmacol 50:177

23. Rojas J, Green RS, Hellerqvist CG, Olegand R, Brigham KL, Stahlman MT 1981 Studies on Group B beta-hemolytic Streptococcus. II. Effects on pulmonary hemodynamics and vascular permeability in unanesthetized sheep. Pediatr Res 15:899

24. Rojas J, Larsson LE, Ogletree ML, Brigham KL, Stahlman MT 1983 Effects of cyclo-oxygenase inhibition on the response to Group B streptococcal toxin in sheep. Pediatr Res 17:107

25. Salmon JA 1978 A radioimmunoassay for 6-keto-prostaglandin PGF $_{1}-\alpha$. Prostaglandins 15:383

26. Short BL, Miller MK, Fletcher JR 1982 Improved survival in the suckling rat model of Group B streptococcal sepsis after treatment with nonsteroidal anti-inflammatory drugs. Pediatrics 70:343

27. Snapper JR 1981 Septic pulmonary edema. Sem Respir Med 3:92

28. Spannhake EW, Colombo JL, Craigo PA, McNamara DB, Hyman AL, Kadowitz PJ 1983 Evidence for modification of pulmonary cyclo-oxygenase activity by endotoxin in the dog. J Appl Physiol 54:191

29. Tilden SJ, Cowen KH, Wegmann MJ, Kadowitz PJ 1982 Evidence that the airway effects of arachidonic acid are largely due to thromboxane. Clin Res 30:911 A

30. Utsunomiya T, Krausz MM, Levine L, Shepro D, Hechtman HB 1982 Thromboxane mediation of cardiopulmonary effects of embolism. J Clin Invest 70:361

31. Webb PJ, Westwick J, Scully MF, Zahavi J, Kakkar VV 1981 Do prostacyclin and thromboxane play a role in endotoxic shock? Br J Surg 68:720

32. Wise WC, Cook JA, Eller T, Halushka PU 1980 Ibuprofen improves survival from endotoxic shock in the rat. J Pharmacol Exp Ther 215:160 